\title{
Earth Flows Along Henry Creek, Northern Alaska
}

\author{
L. DAVID CARTER ${ }^{1}$ and JOHN P. GALLOWAY ${ }^{1}$
}

\begin{abstract}
Many earth flows occurred during the summer of 1979 in the hilly terrain near Umiat, Alaska, particularly along Henry Creek. Most were shallow, involving only the tundra mat and no more than $1.5 \mathrm{~m}$ of the underlying mud. The summer of 1979 was the warmest and wettest for the period of record at Umiat, and precipitation was characterized by brief but intense localized rainstorms. Failure probably was triggered by the heavy rains and facilitated by an absorbent tundra mat over a clayey substrate, and perhaps in some cases by a thicker than normal active layer. Flows of this kind have occurred repeatedly in the Umiat area, most likely during summers in which climatic conditions were similar to those of 1979.
\end{abstract}

Key words: earth flows, rainfall, temperature, active layer, bentonitic materials, Alaska

\section{INTRODUCTION}

Numerous fresh slope failures were observed in the hilly terrain north of Umiat, Alaska between the Colville and Ikpikpuk rivers during a helicopter reconnaissance in late July, 1979. Slope failures were especially abundant along the 25-km length of Henry Creek (Figs. 1 and 2) where 94 individual failures were present. Because of their unusual abundance, the Henry Creek slope failures were photographed from the air on August 27 so that year-to-year changes could be monitored. In addition, two of the failures were investigated on the ground that day. Because flowage of mud in a thin zone appears to be an essential element of most of these failures, they are assigned to the earth flow category of Varnes's (1978) classification of slope movements. In most of the flows, however, vegetal debris makes up the bulk of the material that moved downslope.

\section{DESCRIPTION}

Relief in the hilly terrain of the Henry Creek drainage basin ranges from 35 to $180 \mathrm{~m}$, and valley-side slope angles range from a few degrees to about 20 degrees. All slopes are covered by shrub tundra except where undercut by Henry Creek. Rocks underlying the drainage basin are perennially frozen, poorly indurated clay, silt, and shale of the Cretaceous Prince Creek Formation (Brosgé and Whittington, 1966).

Most of the earth flows occur on the east side of the creek where local relief is greatest and slopes are steepest. The flows occur on slopes that face in all directions, and preferential distribution because of slope aspect is not apparent in regard to either insolation or accumulation of drifting snow. They are most numerous in valley-side swales, probably because runoff is concentrated there. Some earth flows extend from just below the crestal convexity of the valley side to the valley floor, but others occupy only a part of the valley side. The flows range from a few tens of metres to $450 \mathrm{~m}$ long, and from 10 to $50 \mathrm{~m}$ wide. Generally, each flow includes a flat-floored upper part with a nearly vertical scarp at the head and along each side, and a lower part that consists in some cases of a lobe

${ }^{1}$ U.S. Geological Survey, Gould Hall, APU Campus, University Drive, Anchorage, Alaska 99504, U.S.A. of watery vegetal debris and mud and in others of a hummocky pile of vegetal debris that is partly extruded over the undisturbed surface (Figs. 2 and 3). Most of the flows appear to be shallow, extending a maximum of $1.5 \mathrm{~m}$ below the $0.5-$ to $1.5-\mathrm{m}$-thick tundra mat. None of the flows seemed to be active on the day of the investigation, and it is inferred that the period of activity of individual failures is brief; most may have formed in no more than a few hours or a few days.

The smaller of the two earth flows examined on the ground is $32 \mathrm{~m}$ long and $11 \mathrm{~m}$ wide. It occurred on a 16-degree slope in the middle of the valley side (Fig. 1, site A). The upper $14 \mathrm{~m}$ of the length of the flow is a flat-floored de-

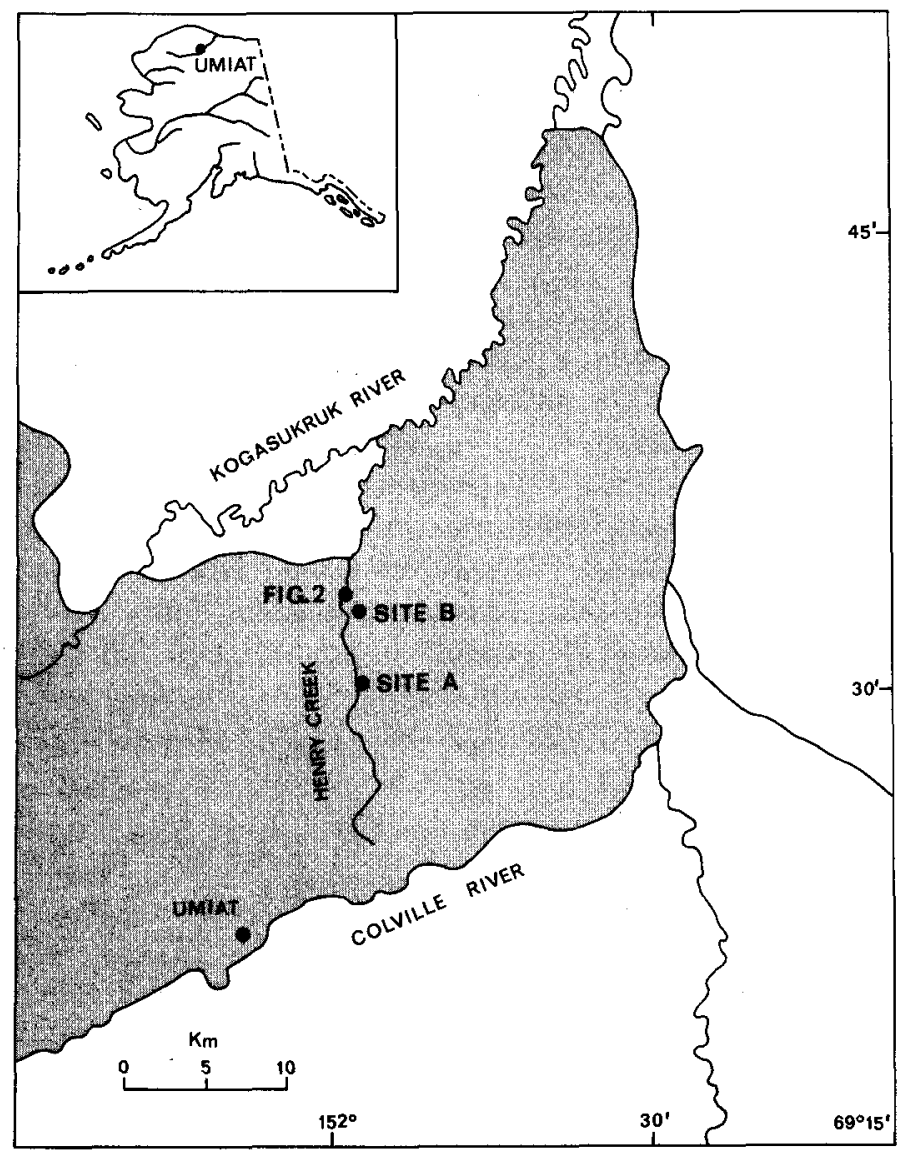

FIG. 1. Location of Henry Creek and of sites mentioned in text. Stippled area is region of hilly terrain where earth flows are common. 


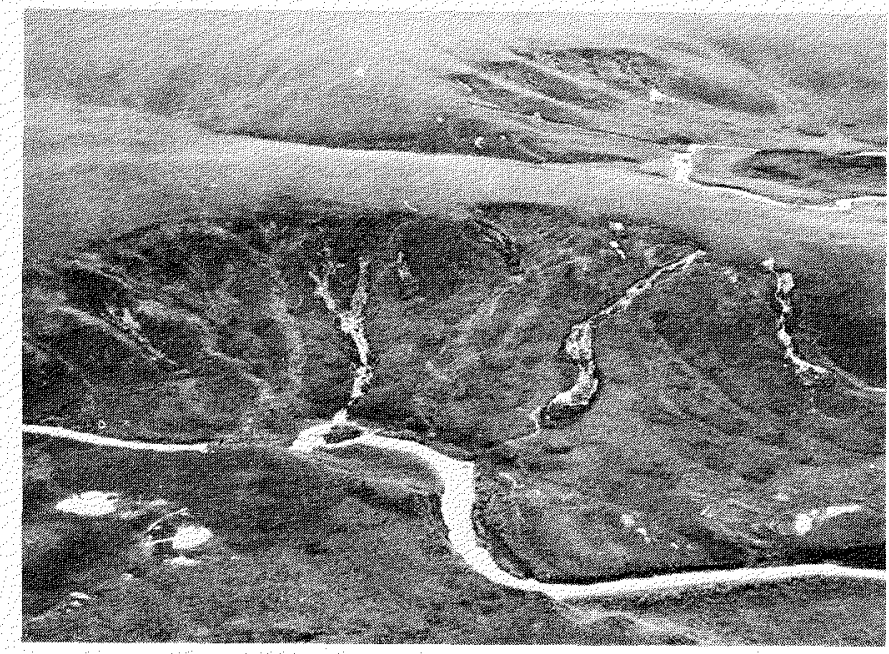

FIG. 2. Earth flows along Henry Creek. The light-toned stripes on the slopes are scars of healed earth flows. See Figure 1 for location.

pression with a scarp at the head and flanking scarps that are $60 \mathrm{~cm}$ high. The tundra mat was completely removed from this zone and the floor had well-developed striations (Fig. 3). The lower $18 \mathrm{~m}$ is a hummocky deposit that consists of displaced blocks of tundra and attached basal mud and was largely derived from the upper $14 \mathrm{~m}$ of the flow. In the flat-floored depression, frozen clay was commonly exposed in the floor, and the maximum depth of thawed mud was $10 \mathrm{~cm}$. Random probing through the adjacent tundra mat with a stainless-steel rod showed that the maximum penetration that could be achieved within $30 \mathrm{~m}$ of the flow approximates the height of the bordering scarps. Because bedrock was not exposed in the earth flow and because frozen ground was, the depth of penetration of the rod is assumed to be the depth to the frost table. We conclude that failure occurred along the top of the local frost table and that this flow was recent enough so that little of the exposed frozen ground had thawed.

The larger of the two earth flows (Fig. 2, site B) is about $212 \mathrm{~m}$ long and extends from the base of the crestal convexity of the valley side into the creek. The lower twothirds of the flow occupies the floor of a valley-side swale, and the toe is a fan-shaped lobe of debris that extends into the creek. The flow has an average width of about $14 \mathrm{~m}$ but is $28 \mathrm{~m}$ wide at the head. Adjacent slope angles range from about 14.5 degrees near the head to about 7 degrees over the lower part of the flow. The height of the scarp at the head and of flanking scarps ranged from 1 to $2 \mathrm{~m}$. Post slope-movement runoff has incised an axial channel as much as $1 \mathrm{~m}$ deep into the floor of the lower two-thirds of the flow. Siltstone and claystone are exposed in this channel and are overlain in places by as much as 25 to $30 \mathrm{~cm}$ of muck. Between the muck and the bedrock, lenses and clots of matted peat, twigs, and willow leaves locally mark the base of the flow. Siltstone and claystone also are exposed in the lower half of the scarp at the head of the flow.

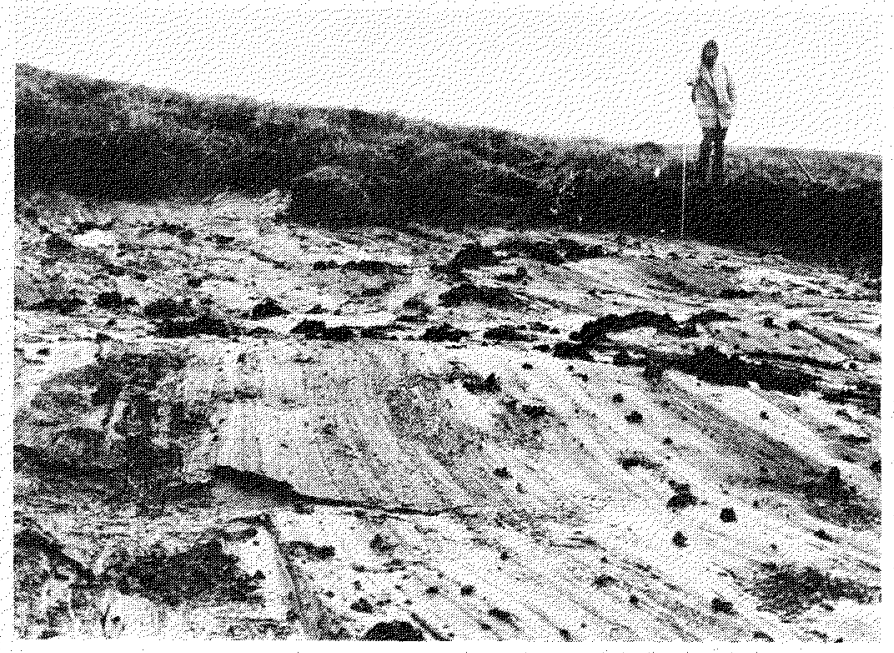

FIG. 3. Striations on the flat floor of the earth flow at Site A.

No clear relation between the frost table and failure could be determined for this flow. In the vicinity of the head of the flow, the stainless-steel probe could be pushed to depths of from $60 \mathrm{~cm}$ to $1.3 \mathrm{~m}$, which approximates the depth to bedrock as exposed in the scarp. Halfway down the slope, maximum penetration of the probe was from 64 to $89 \mathrm{~cm}$, but the floor of the flow was as much as $2 \mathrm{~m}$ below the adjacent tundra surface. Thus it appears that failure may have occurred below the frost table. Furthermore, exposures in the axial channel show that the base of the flow at least locally coincides with the top of bedrock, and exposures in the scarp at the head of the flow demonstrate that failure there occurred within bedrock.

\section{ORIGIN}

Formation of the earth flows was doubtless facilitated by the high clay content and poor induration of the rocks along Henry Creek. Furthermore, the fine-grained beds of the Prince Creek Formation are commonly bentonitic (Brosgé and Whittington, 1966) and are known to include numerous beds of nearly pure montmorillonite (Anderson et al., 1969). Although we have not analyzed samples of the strata exposed along Henry Creek, it seems likely that these beds are typical of the formation. If so, easily hydrated inherently unstable bentonitic materials may be important to the failures reported here. However, they differ from the bentonite debris flows on bluffs along the Colville River described by Anderson et al. (1969), in that those developed on slopes which are largely unvegetated and they lack discrete failure planes or zones. The Colville River bluff flows also possess symmetrical, U-shaped channels through which several flows may pass during a season, and may be active for more than one season.

Fresh earth flows were not observed along Henry Creek during previous field seasons $(1977,1978)$, and only two new flows were observed during 1980 . Many revegetated scars of older flows are visible from the air (Fig. 2) and on 
aerial photography taken in 1948, and many of the 1979 flows occurred at the sites of earlier failures in valley-side swales. Formation of the flows is apparently episodic, and conditions must have been especially favorable for their development during 1979.

Weather records at Umiat (Table 1) show that the summer of 1979 was both warmer and wetter than any other summer during the period of record. Winter snowfall, however, was below the mean. May of 1979 was unique in that no snow cover was recorded, and it was the only May during the period in which the mean temperature was positive.

Surcharge resulting from the weight of rain and decreased shear strength due to wetting are common causes of slope movements (Varnes, 1978). The occurrence in valley-side swales of many of the 1979 earth flows and of previous earth flows suggests that the concentration of runoff aided in their formation, and the abnormally heavy rainfall of 1979 , which was $4.68 \mathrm{~cm}$ above the mean, may have been a key factor in initiating the earth flows. No earth flows formed along Henry Creek during 1977 and 1978, and these were comparatively dry years. The character of the rainfall, however, is perhaps as important as the amount, inasmuch as studies by Caine (1980) document that the failure threshold for shallow landslides and flows can be defined by a product of rainfall intensity and duration. In this regard, we observed that during our fieldwork in 1979 (July 12 through September 4), precipitation was concentrated in brief but intense localized rainstorms. Moreover, $5.08 \mathrm{~cm}$ of the total rainfall recorded that year at Umiat (37

TABLE 1. Weather and snowcover data for Umiat, Alaska

\section{A. \\ A. Rainfall ( cm) \\ (May through September)}

\begin{tabular}{ccr} 
Year & Total & Departure \\
& & mean \\
1979 & 13.63 & +4.68 \\
1978 & 5.70 & -3.24 \\
1977 & 7.53 & -1.41 \\
& & \\
1976 & incomplete data \\
1955 & through 1975 no dat \\
1954 & incomplete data \\
& \multicolumn{3}{c}{} \\
1953 & 12.53 & +3.58 \\
1952 & 7.64 & -1.30 \\
1951 & 13.60 & +4.65 \\
1950 & 5.05 & -3.89 \\
1949 & 4.58 & -4.36 \\
1948 & 10.24 & +1.29
\end{tabular}

$\bar{x} \quad 8.94$

75.24
C. May snowcover $(\mathrm{cm})$

B. Snowfall (cm)
(September through May)

\begin{tabular}{|c|c|c|c|c|}
\hline Winter & Total & $\frac{\text { Departure from }}{\text { mean }}$ & Year & $\frac{\text { Maximum depth }}{\text { on ground }}$ \\
\hline $\begin{array}{l}1978-79 \\
1977-78 \\
1976-77\end{array}$ & $\begin{array}{l}69.59 \\
85.85 \\
96.50\end{array}$ & $\begin{array}{r}-5.65 \\
+10.61 \\
+21.26\end{array}$ & $\begin{array}{l}1979 \\
1978 \\
1977\end{array}$ & $\begin{array}{r}0.00 \\
30.48 \\
53.34\end{array}$ \\
\hline
\end{tabular}

1954-55 through 1975-76 no data

1955 through 1976 no data

$\begin{array}{lll}1953-54 & 58.42 & -16.82 \\ 1952-53 & 71.62 & -3.62 \\ 1951-52 & 62.74 & -12.50 \\ 1950-51 & 79.50 & +4.26 \\ 1949-50 & 79.76 & +4.51 \\ 1948-49 & 73.19 & -2.05\end{array}$

1954

1953

1952

27.94

1951

1950

1949

1948

25.40

33.02

12.70

33.02

53.34

no data

D. Temperature $\left({ }^{\circ} \mathrm{C}\right)$

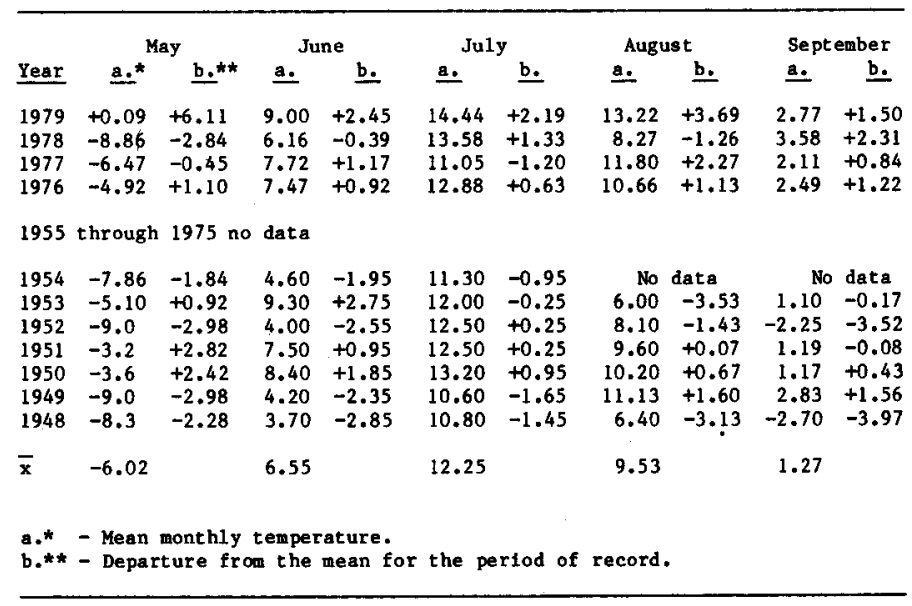

percent of the total rainfall) occurred on June 25 and probably represents one or more short, intensive storms. Rainfall of this kind may have caused the local threshold of failure to be exceeded at numerous sites in the foothills north of Umiat. In this area, a critical factor in that threshold may be the increasing weight of the highly absorbent tundra mat as water is added faster than it can drain away.

Studies by Brown (1969) near Barrow show that a thicker active layer may develop during warm wet summers than during cool dry ones. A light winter snowfall coupled with unusually warm May temperatures to produce an early absence of snowcover would also promote development of a thick active layer. The temperature, rainfall, snowfall and snow cover data suggest, therefore, that conditions 
were favorable during 1979 for development of a thicker active layer than during the previous summers of record. Increased thickness of the active layer would allow an increase in surcharge due to rainfall. In places where the permafrost table is normally above the mineral soil and within the tundra mat, an increase in the thickness of the active layer to below the tundra mat would facilitate a decrease in shear resistance due to wetting of the underlying clayey materials. Unfortunately, we do not have sufficient measurements of active layer thickness for various years and differing geomorphic settings to allow us to evaluate this possibility. Moreover, although failure at Site A appears to have occurred at the base of the active layer, no clear relation between the active layer and failure at Site B could be determined.

On the basis of the field observations and climatic data, we favor a hypothesis that the earth flows resulted from a combination of an unusually warm, wet summer, a highly absorbent tundra mat in which thawing had begun early due to little or no May snow cover, and a fine-grained, unstable substrate. Heavy summer rains concentrated in brief but intense localized rainstorms probably triggered the slope movements, and some may have been facilitated by a thicker-than-normal active layer. If this is correct, then new earth flows should form during summers in which climatic conditions are similar to those of 1979. However, if a saturated tundra mat is a prerequisite of this type of earth flow, then new flows should not develop on the 1979 sites until revegetation has occurred.

\section{ACKNOWLEDGEMENTS}

We thank T.D. Hamilton and W.E. Yeend for critical reviews of the manuscript.

\section{REFERENCES}

ANDERSON, D.M., REYNOLDS, R.C., and BROWN, J. 1969. Bentonite debris flows in northern Alaska. Science 164(3876):173-174.

BROSGÉ, W.P. and WHITTINGTON, C.L. 1966. Geology of the Umiat-Maybe Creek region, Alaska. United States Geological Survey Professional Paper 303-H. 836 p.

BROWN, J. 1969. Soil properties developed on the complex tundra relief of northern Alaska. Biuletyn Peryglacjalny 18:153-167.

CAINE, N. 1980. The rainfall intensity-duration control of shallow landslides and debris flows. Geografiska Annaler 62A (1-2):23-27.

VARNES, D.J. 1978. Slope movement types and processes. In: Schuster, R.L., and Krizek, R.J. (eds.). Landslides, Analysis and Control. Transportation Research Board Special Report 176. Washington, D.C.: National Academy of Sciences. 11-33. 